ROCZNIKI HUMANISTYCZNE

Tom LXVIII, zeszyt $12-2020$

DOI: https://doi.org/10.18290/rh206812-5

REV. PIOTR WIŚNIEWSKI

\title{
A NINETEENTH-CENTURY PROCESSIONAL FROM THE ARCHIVE OF THE BONIFRATRES \\ IN CRACOW (KRAKÓW). A CONTRIBUTION TO RESEARCH INTO LATIN MONODY
}

An indispensable element of any historical study is research into sources. Their multifarious analysis and scholarly reflection enable an indirect knowledge of past reality. Musico-liturgical manuscript books belong in this respect among the particularly engaging and valuable documents. This stems from each preserved codice being an original work reflecting both the characteristic traits of its epoch, and indicating the manner of worship of God in times of its use. Finally, it constitutes a valuable testimony of local liturgical customs, diocesan and monastic.

The object of this study is a modestly-sized "Processyonał" (call no. rkps 38) kept at the Archive of the Bonifratres Monastery in Cracow. According to determinations by Marek Bebak, it made its way into the Bonifratrian book collection in the nineteenth century (Bebak 25-26). However, determining from which collection it originates and how it entered the Bonifratres' book collection poses challenges. The manuscript is decisively of textbook character destined for daily liturgical needs. The present communiqué, aimed at presenting the codex, is an academic contribution to further study on the liturgi-

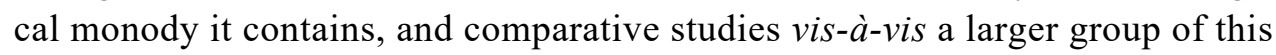
book type. Its confrontation with other, earlier sources will allow to determine to which degree this local book copies their repertoire, what chant it abandons,

Ks. dr hab. PIOTR WIŚNIEWSKI, prof. KUL - Katolicki Uniwersytet Lubelski Jana Pawła II, Instytut Nauk o Sztuce; adres do korespondencji: Al. Racławickie 14, 20-950 Lublin; e-mail: wisniewskipiotr@op.pl. ORCID: https://orcid.org/0000-0001-8225-7552.

Rev. dr habil. PIOTR WIŚNIEWSKI, associate professor - The John Paul II Catholic University of Lublin, The Institute of Art Studies; address for correspondence: Al. Racławickie 14, 20-950 Lublin, Poland; e-mail: wisniewskipiotr@op.pl. ORCID: https://orcid.org/0000-0001-8225-7552. 
and which possible new chant it offers. This type of examination will assist in evaluating the studied processional's originality.

According to the encyclopaedic definition, a processional is a liturgical book containing the texts of antiphons destined to be sung in procession. In the twelfth and thirteenth centuries, it was treated as a separate book, and subsequently supplied with ritual norms. In turn, in the fifteenth and sixteenth centuries, the processional became a strictly utilitarian "go-to" book, with among others, funeral antiphons, antiphons of Maundy Thursday's Mandatum ritual, and antiphons performed at the Adoration of the Cross on Good Friday (Nadolski 1228). The antecedent of the processional was a specific part of graduals, containing a catalogue of antiphons for April 25-the so-called Greater Litany, Rogationes (Paćkowski 28). The processional's constitution as a separate book resulted from transferring processional antiphons from the gradual to a smaller book to be carried in procession and amenable to new chant being entered. However, according to Piotr Paćkowski, the current encyclopaedic definition is not sufficiently adequate in regard to its content. Taking into account the entire process of this book's development, he proposes a much wider definition:

\begin{abstract}
The processional is a liturgical book of the Western Church containing chant, rubrics, and descriptions of ritual connected with processions recommended by the Apostolic See, e.g. for the Feast of the Purification of the Blessed Virgin Mary, Palm Sunday, Resurrection Sunday, (...), chant connected with procession before the main Holy Mass on Sundays and church holidays. Depending on the musical needs of a given centre it may contain antiphons, responsorials, verses, sequences, and even polyphonic works absent from other liturgical books. (32)
\end{abstract}

Thus, the processional appears as a rather voluminous - and, in terms of liturgical repertoire-variegated book, meaning that it does not constitute a monolith or time-set model to be rigorously observed at each edition of new such book. Moreover, the processional was not originally an official liturgical book. It was prepared as destined for a particular cantor, which is testified by some manuscripts individually naming the person to perform its chant (Nadolski 700) ${ }^{1}$. The first "processionale" for Poland as a whole appeared in Cracow in 1621. It simultaneously furnished a point of reference

\footnotetext{
${ }^{1}$ Thus, one that has been approved by the appropriate church authority and containing texts of rituals, prayers, and the order of holy days. It is used in the exercise of the public worship of the church (Greniuk 260); In the strict sense it is a collection of euchological texts, comprised of prayer formulas and ceremonial directions, independently of its use in public worship (Boguniowski 40).
} 
for liturgical service in a territory where, until then, offending license existed. Processions were mainly connected with the monastic rite of their origin. With those remarks in mind, we shall examine the Cracow item, shedding some light on it.

\section{SOURCE PRESENTATION}

The examined processional is a book of these dimensions: height: $22.5 \mathrm{~cm}$, width: $19.5 \mathrm{~cm}$, thickness: $1.8 \mathrm{~cm}$; it is bound in hardcover made of cardboard. It has a title page, on which the title has been inscribed in a black-red font, announcing the book's content, publishing address, and the edition's author. The title page states:

"T.M.J. ${ }^{2}$ PROCESSIONAL Antiphons, Responsorials, and similar [music], customarily sung on Processions throughout the year and containing an Officium Defunctorum with [given] Conducts.

Set according to the Holy Roman Catholic Church Office in Musical Chant Notes, elucidated in part through Polish translations of the necessary rubrics, written out for the [reading] comfort of Church Officials. in Limanowa. 1811 R. Per me Joannem Smoroński"’3. Before the title page, awritten addition was made a posteriori, as evidenced by a different ductus, presenting the texts of four church songs: "Twoja cześć, chwała" [Your Honour and Glory], "Boże w dobroci" [God, in Thy Goodness], "Do ciebie Panie pokornie wołamy" [To You, Oh God, We Meekly Call], "Panienko moja, któraś Pana" [My Lady, Who Has the Lord...]. The book's end, in turn, carries the texts of three Latin texts: "Salve Regina", "Maria Mater gratiae", "Ave Maris stella", and one song in Polish: "Zmarły człowiecze, z tobą się żegnamy" [Dead Human, We Bid You Goodbye].

The work has a double foliation. The upper corners most probably carry what is the original pagination (with some pages lacking it); in turn the lower corners, a later (complete) pagination including the pages with the texts added before the title page and at the book's end.

\footnotetext{
${ }^{2}$ Unknown abbreviation.

3 “T.M.J. PPROCCESYONAŁ Antyfony, Responsoria y tym podobne na Procesyach przez cały rok śpiewać się zwykło, tudzież Officium Defunctorum z Konduktami zawierający. Podług obrządku Kościoła Świętego Rzymsko-Katolickiego Muzycznemi Notami Chorałowemi ułożony, częścią Polskim tłumaczeniem potrzebnych Rubryk objaśniony, dla wygody Officyalistów Kościelnych, wypisany. w Limanowy. 1811 R. Per me Joannem Smoroński”.
} 
The manuscript's contents are prepared with a good-quality black and red ink on paper leaf of gray-yellow hue. Written out in black, we have the liturgical content, while with red, the staff, rubrics (in Polish), initial letters of every chant, and the beginning letter of each sentence. The titles of liturgical periods are written out in red, and partly, black. The author applies decorative elements uniformly throughout the book. They seem to be aimed at not only breaking the monotony of the text, but also assisting in quick orientation in layout.

The musical material is placed on a four-line stave. The author uses two clefs in the notation of melody: $c$ and $f$. From the chromatic signs a flat appears, as a signature sign or part of the music. In several places it is cancelled by a natural sign. It may occur that an entire piece has a natural right beside the clef in every stave, e.g. in "Absolve Domine" (113) to remind performers that it must be sung without the flat. The following neumes participate in melodic:

punctum
virga
pes
clivis
scandicus
climacus
torculus
porrectus
distrofa
epiphonus

Epihonus as a liquescent sign is a significant criterion that points at the neumatic tradition ${ }^{4}$. In the processional, this neume is notated regularly as a completion of basic neumes. In turn, the Cracovian monument does not have the quilisma. It is worth noting that it was not generally used in Polish chant books (Pawlak, Graduaty piotrkowskie 88; Gieburowski 75; Bodzioch,

\footnotetext{
${ }^{4}$ The aptitude of the liquescence sign stems from the nature of liquescence itself, which transmits the linguistic phenomenon onto musical territory with ease. Their appearance is connected to defined phonetic instances in the text. It is predominantly observed in places where a liquid consonant is followed by another consonant, e.g. ille, or at the occurrence of dyphtongs, e.g. eius (Bernagiewicz 80-83).
} 
Antyfonarze Piotrkowczyka 61; Wiśniewski 68). Most probably, this results from the unification of musical notation. Attention was focused on notating the relative pitch, while omitting details connected to their performance (Adamko 37). A characteristic of the studied collection is that, fundamentally, only single, two-note, and three-note neumes appear. Even when a syllable carries a higher number of notes, in notation it is most often a collection of particular two- and three-note neumes (Paćkowski 45). Neumes, depending on the particular need, are linked into more elaborate melodic figures, forming melismas. In the melodic course, the author applies two dividing lines (divisio maior and divisio maxima). Also encountered in the processional is a small oblique line, placed between notes as a sort of distinguishing sign. These lines, representing a graphico-interpunctive element, divide the musical notation into smaller melodic units to facilitate textual and melodic reading 5 . Each musical stave ends with a custos, always in identical rhomboid form, with one characteristic line curled upwards and ended with a kind of loop, as pictured in the facsimile below. This sign is notated also within the stave, at the occurrence of change in clef placement. Also encountered in the melodic notation is the distrophe, whose puncta are linked using a characteristic 'binding bracket'. A frequent application of this figure (21 times) occurs in the antiphon "Rex Christe primogenite" (70):

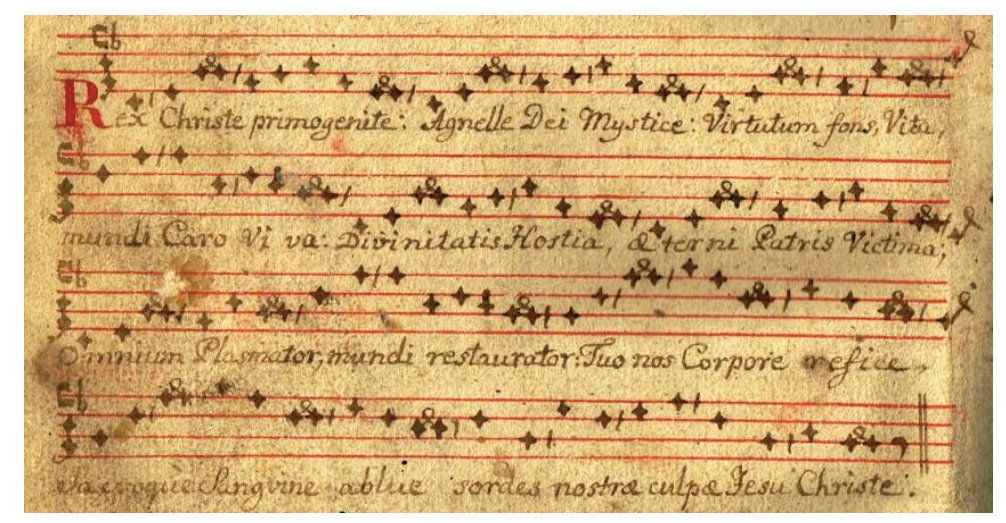

Example 1. Rex Christe primogenite

${ }^{5}$ This is not an isolated practice. It is already known from certain mediaeval manuscripts (Norek 106). 
Off-white paper strips of various dimensions glued to the edges of many leaves, and in several places directly onto them, in both cases to secure damaged locations, as well as many visible soils and dark-gray blotches, testify to an intensive use of the processional. In several locations, strips of paper are glued directly below the entire staff with Latin text $(46,117)$. Generally speaking, the appraisal of the book's state is favourable: its good condition makes it amenable for use.

\section{MUSICAL CONTENTS}

The book is comprised of several parts, although not all are directly announced. However, taking into account the book's liturgical content, we can distinguish the following five book parts presenting full works (text and music):

I. Processionalis Ordinarium-contains antiphons and responsorials connected with service stemming from the Sunday cycle. This part opens with the antiphon "Haec est dies" sung before the ritual of asperges, followed by the antiphon "Asperges me" with two melodies, of which the first is destined for year-round singing, while the second exclusively for "White and Flower Sunday"; furthermore, "Vidi aquam" for Resurrection Sunday and the octave. Subsequent chant encompasses selected days and Sundays of Lent: $\mathrm{Fe}$ ria quarta Cinerum (ant. before Ash Wednesday Benediction "Exaudi nos Domine", and two antiphons ad libitum after the sprinkling with ashes, "Immutemur habitu" and "Inter vestibulum", resp. "Emendemus in melius"); Dominica Palmarum (ant. "Osanna Filio David", resp. "Collegerunt Pontifices", "Sanctus", ant. "Pueri Haebreorum portanes", ant. "Pueri Haebreorum vestimenta", ant. "Cum appropinquaret Dominus", hymn "Gloria laus et honor", resp. "Ingrediente Domino"). Subsequent chant relates to the Paschal Triduum celebration: Feria Quinta in Coena Domini (with lacking melody), Feria Sexta in Parasceve (tractus "Domine audivi", tractus "Eripe me Domine", "Ecce Lignum Crucis", Improperium I: "Popule meus", “Agios o Theos", "Sanctus Deus", Improperium II: "Quia eduxi", Improperium III: "Quid ultra debui", ant. "Crucem tuam", hymn "Crux fidelis", hymn "Vexilla Regis", resp. "Recessit Pastor", ant. "Tibi laus"), Sabbato Sancto ("Lumen Christi. Deo gratias", 4 tracti: "Cantemus Domino", "Vinea facta est", "Attende de Coelum", "Sicut cervus", "Alleluia", ant. ad Magnificat "Vespere autem"), Dominica Resurrectionis Domini (ant. "Gloria Tibi Trinitas", "Surrexit Dominus"), Processio Paschalis ante Missam (ant. "Cum Rex glo- 
riae", hymn "Salve Festa Dies", ant. "Sedit Angelus"), In Festo Sancti Marci Evangelistae (ant. "Exurge Domine"), Antiphonae Suffragiorum-texts with antiphonal music for various occasions: De Sancto Spiritu ("Veni Sancte Spiritus"), Extra tempus Paschale De s. Cruce ("Per Signum Crucis"), Tempore Paschali De S. Cruce ("Crucem Sanctam subiit"), Tempore Paschali De Beata Maria V. ("Regina Coeli"), Extra Tempore Paschali De B. Maria V. ("Sancta Maria"), De Apostolis Petro et Paulo ("Gloriosi principes"), Pro S. Marco ("Sancti tui Domine"), De S. Adalberto ("Per merita Sancti Adalberti"), De S. Stanislao ("Vir inclyte Stanislae"), De S. Venceslao ("Corde lingua"), De S. Floriano ("In Floriano latuit"), De S. Hedvigi ("Hedvigis Sancta inclyta"), Contra hostes Ecclesiae ("Contere Domine"), Pro Rege ("Quoniam Rex noster"), Pro Serenitate vel pluvia ("Domine rex"), Tempore pestis ("Media vita"), Pro Pace ("Da pacem Domine"), Tempore Paschali pro Sanctis ("In coelestibus Regnis"), Extra Tempus Paschali pro Sanctis ("Sancti Dei omnes"), In Festo Ascensionis Domini (resp. "Ite in universum orbem", v. "Oramus Domine conditor", ant. "Ascendo ad Patrem meum"), Dominica Pentecostes (resp. "Apparuerunt Apostolis", hymn "Veni Creator Spiritus", ant. "Accipite Spiritum Sanctum"), In Festo Sanctissima Trinitatis (resp. "Duo Seraphim", ant. "Pax aeterna", ant. "Salvator mundi"), In Solemnitate SS. Corporis Christi (responsoria: "Homo quidam", "Immolabit haedum", "Respexit Elias", "Misit me", ant. "O Sacrum convivium", resp. "Melchisedech Rex", ant. "Rex Christe primogenite").

II. Proprium Sanctorum - contains chant for feasts and commemorations of saints. These are: In Festo Purificationis B. Virginis Mariae (antiphons: "Lumen ad revelationem gentium", "Adorna thalamum", "Responsum accepit Simeon", resp. "Obtulerunt pro eo Domino"), In Festo Assumptionis B.V. Mariae (responsorials: "Vidi speciosam", "Beata es Virgo Maria").

III. Commune Sanctorum - carries the In Festo Divisionis SS. Apostolorum without chant presentation. The rubric gives solely the textual incipit of "Te Deum laudamus".

IV. Officium Defunctorum - in this part we find Vespers, Matutinum, and Laudes. For all Officium antiphons, a text and melody is presented, as well as the given psalm's text and differentia (euouae). Melodies also exist for all the Matutinum responsorials.

Ad Vesperas: ant. "Placebo Domino", ps. "Dilexi quoniam"; ant. "Hei michi Domine", ps. "Ad Dominum"; ant. "Dominus custodit", ps. "Levavi oculos"; ant. "Si iniquitates", ps. "De profundis"; ant. "Opera manuum", ps. "Confitebor tibi"; ant. ad Magnificat "Omne quod dat mihi Pater"; Ad Matutinum Invita- 
torium: ant. "Regem cui omnia"; In primo Nocturno: ant. "Dirige Domine Deus", ps. "Verba mea auribus"; ant. "Convertere Domine", ps. "Domine ne in furore"; ant. "Ne quando rapiat", ps. "Domine Deus"; resp. "Credo quod Redemptor meus"; resp. "Qui Lazarum"; resp. "Domine quando veneris"; In secundo Nocturno: ant. "In loco pascuae", ps. "Dominus regit"; ant. "Delicta iuventutis", ps. "Ad te Domine levavi"; ant. "Credo videre", ps. "Dominus illuminatio mea"; resp. "Memento mei Deus"; resp. "Heu mihi Domine"; resp. "Ne recorderis peccata mea"; In tertio Nocturno: ant. "Complaceat tibi Domine", ps. "Expectans expectavi"; ant. "Sana Domine", ps. "Beatus qui"; ant. "Sitivit anima mea", ps. "Quemadmodum desiderat"; resp. "Peccante me"; resp. "Domine secundum actum meum"; resp. "Libera me Domine"; resp. "Libera me Domine de morte"; Ad Laudes: ant. "Exaltabunt Domino", ps. "Miserere mei"; ant. "Exaudi Domine", ps. "Te decet hymnus"; ant. "Me suscepit", ps. "Deus, Deus meus"; ant. "A porta inferi", ps. "Ego dixi"; ant. "Omnis spiritus", ps. "Laudate Dominum"; ant. ad Benedictus "Ego sum resurrectio".

V. Processio pro Fidelibus Defunctis - contains the ceremony of procession to the cemetery, which has five stations on November 2. It presents a complete notation of the responsorial melody "Absolve Domine animas eorum", copies of prayer texts, and textual incipits of responsorials for each station, as well as the textual incipit of antiphon "Salve Regina" for the procession's close. This book part refers to the ceremony of mourning conduct by adults and children with the chant: Conductus Adultorum: resp. "Subvenite Sancti Dei", ant. "In paradisum"; Conductus Parvulorum: ant. "Sit Nomen Domini", ant. "Hic accipi", ant. "Iuvenes et virgines".

In general, the manuscript contains 118 chants of various kinds: 72 antiphons, 26 responsorials, 5 hymns, 6 tracti, 1 Sancti, 1 verse, 5 pieces in improperia, and 2 invocations. To this we must also add 21 Psalmic differentia (euouae), which produces a total of 139 melodies. In great majority (98), these are pieces belonging to the basic corpus of chant performed in procession (responsorials-as the longest chant-during the conduct; antiphons-as a shorter one typical for a given holiday-at the station). If we weigh the variegation of processional books' contents in earlier historical periods ${ }^{6}$, it seems that the author of the Cracow example, by including this and no other content, was guided by local liturgical needs, to which he was fully authorized,

\footnotetext{
${ }^{6}$ Processionals are known containing uniquely antiphons $\left(12^{\text {th }} \mathrm{c}\right.$. France), or antiphons and responsorials (beginning from the $16^{\text {th }} \mathrm{c}$.). For example, the Dominicans in the $13^{\text {th }} \mathrm{c}$. used processionals only having responsorials; in turn, Franciscans, books limited to processions on February 2, Palm Sunday, and funeral procession; and finally, the Canons Regular and Premonstrates had a greater inclusion of antiphons than responsorials (Paćkowski 29-32).
} 
since the processional did not belong to the canon of the Common Church's official books. It was a book used in particular monastic orders and monasteries.

\section{COMPARATIVE STUDY OF THE CODEX WITH OTHER SOURCES}

Variety in the way liturgical service was held and the music connected with it before the Council of Trent caused a number of controversies. For this reason, their unification was awaited in earnest, to put order to this sphere of the Church's activity. In this connection, efforts were made to have liturgical books published in destination for the Common Church (Pawlak, Tridentinum i Vaticanum II 307). A reference point for holding liturgical service in Poland as an entirety in the seventeenth century became Andrzej Piotrkowczyk's Processionale from 1621, which constituted a basis for performing chant in procession for nearly 200 years. Subsequently, there appeared cancionals, which to a large degree assumed the function of processionals (Paćkowski 23). Taking into account these circumstances, we shall juxtapose the processional from the Bonifratres monastery $(=\mathrm{Pkr})$ first with the Codex of Piotrkowczyk ${ }^{7}(=\mathrm{PP})$, and next, with the contents of selected nineteenth-century cancionals, to determine to which degree the examined manuscript retained the "typical" processional repertoire, which chant it abandoned, and which other it might have added.

A comparative analysis reveals that $\mathrm{Pkr}$ in relation to Piotrkowczyk's print (285 chants) abandons a total of 146 chants. In the part Processionalis Ordinarium, Pkr presents 57 melodies, while PP notates 102. Pkr omits all chant for Advent Sundays, the Christmas period, the pre-Lenten period, Lent (except Palm Sunday), and some auxiliary antiphons (suffragiorum). However, Pkr includes chant that in turn lacks in PP. These are the following antiphons: "Haec est dies", "Inter vestibulum", "Pueri Haebreorum portanes", "Pueri Haebreorum vestimenta", "Per Signum Crucis", "Crucem Sanctam subiit", "Sancta Maria", "Sancti tui Domine", "Vespere autem", tracti (6), supplication "Ecce Lignum Crucis", and the "Alleluia" Gospel Acclamation. The greatest agreement of repertoire between the two collections is exhibited by antiphons destined for various occasions. This is surely proof that the manuscript from 1811 retained liturgical acts that were strongly rooted in the Polish tradition, among them antiphons from rhymed Officiums to the glory of patrons of Poland, St. Adalbert,

\footnotetext{
${ }^{7}$ We are using the chant list from the work by Paćkowski (Paćkowski 233-240).
} 
St. Florian, and St. Stanislaus. This is because other musico-liturgical books (antiphonaries, graduals) have also maintained them.

Ranking particularly modest is the music gathered in the Proprium Sanctorum PKr. The author of this Cracow manuscript' notates only 6 chants for two holidays, whereas AP in this part of book offers as many as 43 holidays and 84 chants. In turn, the section Commune Sanctorum of PKr does not offer any chant. In comparison, the PP prints here 14 formulae and 48 chants. Identical with PP is only the Breviary Officium for the Dead, which confirms its structural invariability over reforms introduced in the officium divinum during liturgical history ${ }^{8}$. Moreover, $\mathrm{Pkr}$ affords a separate book part for processional service for the dead. PP offers only, and not as a separate book part, the procession In Die Commemorationis Omnium Fidelium Defunctorum for November 2, with the chant "Absolve Domine animas eorum" marked as antiphon. Mention is lacking about mourning conducts. In this respect, the manuscript from 1811 is a more ample book, enriched by the rite of walking the body to the cemetery, which testifies to its utility also outside the church. This was certainly allowed for by the book's utilitarian format, although the Codex of Piotrkowczyk has similar dimensions: height $-25 \mathrm{~cm}$, width $-19 \mathrm{~cm}$, thickness - 5,5 cm (Paćkowski 36).

The results show that the processional kept at the Cracovian Bonifratres' retains the repertoire of the 1621 Processionale only in part. Nevertheless, the sole fact of such type of manuscript being created still at the beginning of the nineteenth century, when cancionals were already being published on a large scale, reflects the living tradition of frequently organized processions in Poland and utilization of a separate book on such occasion. This undoubtedly testifies to the great attachment of the Polish people to this form of religiousness, and their deep rooting in the native land's rites. It is worth noting that alternately, the Roman Rite from 1614 already lists processions of just the major solemnities of the liturgical year ${ }^{9}$. In this scope, it confirms a clear superiority of Polish books over Roman ones.

\footnotetext{
${ }^{8}$ Based on research by S. Nowak, we know that officium defunctorum differed markedly from the basic pre-council Officium and carried the earmarks of an auxiliary Officium. It omitted a range of constitutive elements of the particular canonic hours, which is proof that over the ages it was not subject to modification, remaining unaltered until the reforms of Vaticanum II (367-373).

${ }^{9}$ These are: "In die festo Purificationis B.M.V", "De processione in Palmarum", "In Litaniarum maiorum Processione quae die festo S. Marci celebratur", "In festo Sanctissimi Corporis Christi", "Processio ad petendam pluviam", "Processio ad postulandam serenitatem", "Processio in quaqumque tribulatione", quoted after (Paćkowski 77-81).
} 
As pointed out earlier, the processionals' repertoire was to a large extent assumed by cancionals, which besides chant in Polish also contained extracts of texts and melodies from official liturgical church books. They included, among others, chant for processions and chant linked with the liturgical year, both in Latin and Polish. Thus, they became liturgical "textbooks" of their own kind. Although the Holy See did not know this type of book, in Poland it was given the rank of a liturgical book, due to its content and the weight it enjoyed in the community (Pawlak, Tridentinum i Vaticanum II 315). A fundamental scholarly preparation on this subject is a monograph by Beata Bodzioch (Cantionale ecclesiasticum), who lists the full contents of nineteenth- and twentieth-century cancionals published on Polish lands. Although they are temporally posterior to the Cracow processional (they were published beginning in 1822), their authors' copying of a range of Latin chant appearing earlier in the processional book signifies their functioning in Church liturgy most certainly even earlier. What the repertoire of cancionals thus largely indicates is foremost a transmission of the all-church tradition. This is particularly evident also from their specific parts' titles furnished in some editions, e.g. Maciej Dembiński's Cantionale ecclesiasticum (Bodzioch, Cantionale ecclesiasticum 243-248) includes analogous sections among its parts, just like Piotrkowczyk's print and the processional from the Archive of the Bonifratres: Processionale Ordinarium, Proprium Sanctorum, Commune Sanctorum, Officium Defunctorum, and the clearly set apart in Pkr Ordo sepeliendi Adultos and Ordo sepeliendi Parvulos. The common practice of reprinting ample chant content from the processional in cancionals testifies to this book's great utility in liturgical ceremonies as late as the mid-twentieth century. The following decades' retracing of a part of processional content in cancionals only proves the value and significance of this local liturgical book for the Church in Poland.

The processional from the Archive of Cracovian Bonifratres, likely one of the last handwritten books of this type and period, is undoubted proof of the high musical culture cultivated in the milieu for which it was prepared, and by the same token, a significant contribution of the Church in Poland to European religious heritage. The fact of such a collection having been edited still in the second decade of the nineteenth century is irrefutable proof of a cherished tradition which, despite many whirlpools of history, lived on almost unchanged until the Second Vatican Council. Despite the fact that in the nineteenth century the processional was supplanted by cancionals, the repertoire of the latter - as has been shown - has not become obsolete, and 
moreover, it is largely the processional's continuation. Also, the Cracow item is testimony of the people being actively involved in processions and chanting in Polish. This is confirmed by a complete inclusion of the lyrics to one of Europe's oldest church songs, "Chrystus Zmartwychwstan jest" (Christ is Risen) (Kabot), preceded by the rubric "Lud śpiewa Pieśń" (The People Sing a Song, p. 45), performed at a resurrection procession. Apart from this song, written out in the manuscript's original part, the beginning and end of the collection includes other added, already mentioned pieces. They testify clearly about the increasing phenomenon of people's participation in liturgical celebrations. This is also how, slowly, Roman liturgy turned into national liturgy, for which the Holy See-paying the price for Church unity as a common goal-gave tacit consent. It is because Rome feared that due to a more radical Polonization of Catholicism in Poland, a national church may arise there ${ }^{10}$.

In conclusion, some questions arise, e.g. how does one explain the presence - in the examined processional - of chant that does not belong to any procession, such as the repertoire of Paschal Triduum or Officium Defunctorum? It is perhaps due to practical reasons. Not all chant notated there was used solely in procession, but it was included to diminish the number of books employed. Moreover, what commands attention is the employment in the Cracow processional of only four lines per stave, while books printed in the seventeenth century already sometimes used five lines. Here, we cannot exclude the author's modelling himself on Piotrków codices. In this respect, cancionals had a freedom (Bodzioch, Cantionale ecclesiasticum 225-227). The hypothesis is supported by the use of gothic script. Final conclusions will, however, only follow research on the processional's melodic version.

Translated by Maksymilian Kapelański

\footnotetext{
${ }^{10}$ Ireneusz Pawlak discusses this in more detail. In his view, the process of a liturgical Polonization already began at the moment of Poland's christening, due to the contact of the new doctrine with local tradition. A bifurcation followed in the liturgy: the clergy was obliged to follow the new norms, while the people were attached to their traditions. There was also a "theatralization" of liturgy based on every major outdoors celebration becoming a theatrical spectacle. Lay melodies applied to church song were increasingly popular. In the seventeenth century, there was a provincialization of the Polish Church. On the other hand, Polish Catholicism turned in global church matters to the common national sphere. Rome was forced to accept this state of matters, having a higher goal in mind. This state of matter, however, rescued Poland from founding a national church. Catholicism in Poland became more native than in earlier centuries. As a consequence, the Polonization of Christianity made Catholicim's victory permanent and strengthened its influence on subsequent generations. For these reasons, Rome expressed a tacit acceptance of manifestation of Polishness in liturgy (Gradualy piotrkowskie 197-198).
} 


\section{BIBLIOGRAPHY}

Adamko, Rastislav. Rękopisy liturgiczne Biblioteki Kapitulnej w Spiskiej Kapitule (Studium liturgiczno-źródłoznawcze. Edycja tekstu). Doctoral thesis, Katolicki Uniwersytet Lubelski Jana Pawła II, vol. 1, Lublin, 2001.

Bebak, Marek. Kultura muzyczna w krakowskim konwencie bonifratrów pod wezwaniem św. Urszuli w latach 1608-1812. Instytut Muzyki i Tańca, 2017.

Bernagiewicz, Robert. Recepcja tradycji neumatycznych $w$ notacji graduału wiślickiego w świetle neum liquescentes. Apostolicum, 1999.

Bodzioch, Beata. Antyfonarze Andrzeja Piotrkowczyka z lat 1600-1645 jako przekaz polskich tradycji liturgiczno-muzycznych na przykladzie oficjów rymowanych (Studium źródtoznawczo-muzykologiczne). Doctoral thesis, Katolicki Uniwersytet Lubelski Jana Pawła II, Lublin, 2005.

Bodzioch, Beata. Cantionale ecclesiasticum na ziemiach polskich w XIX i XX wieku. Polihymnia, 2014.

Boguniowski, Józef Wacław. Rozwój historyczny ksiag liturgii rzymskiej do Soboru Trydenckiego i ich recepcja $w$ Polsce. Unum, 2001.

Gieburowski, Wacław. Chorat gregoriański w Polsce od XV do XVII wieku ze specjalnym uwzględnieniem tradycji i reformy oraz choratu piotrkowskiego. Gebethner i Wolff, 1922.

Greniuk, Franciszek. „Prawodawstwo liturgiczne.” Liturgika ogólna, red. Franciszek Blachnicki, Wydawnictwo KUL, 1973, pp. 247-280.

Kabot, Teresa. Dzieje pieśni wielkanocnej „,Chrystus zmartwychwstat jest”. M.A. thesis, Lublin, 1983.

Nadolski, Bogusław. Leksykon Liturgii. Pallottinum, 2006.

Norek, Jerzy. Graduat franciszkański z Płocka. Studium źródłoznawcze. Ośrodek Studiów Franciszkańskich, 2007.

Nowak, Dolores Monika. Officium defunctorum w języku polskim po Soborze Watykańskim II. Sindruk, 2017.

Paćkowski, Piotr. Śpiewy procesyjne Proprium de Sanctis w Processionale Andrzeja Piotrkowczyka z 1621 r. Studium źródłoznawczo-muzykologiczne. Doctoral thesis, Lublin, 2007.

Pawlak, Ireneusz. „Tridentinum i Vaticanum II-dwa etapy rozwoju monodii liturgicznej.” Liturgia Sacra, t. 12, nr 2, 2006, pp. 307-319.

Pawlak, Ireneusz. Graduaty piotrkowskie jako przekaz chorału gregoriańskiego w Polsce po Soborze Trydenckim. Wydawnictwo KUL, 1988.

Wiśniewski, Piotr. Śpiewy późnośredniowieczne w antyfonarzach płockich z XV/XVI wieku na podstawie responsoriów Matutinum. Polihymnia, 2010. 


\title{
XIX-WIECZNY PROCESJONAŁ Z ARCHIWUM \\ KONWENTU BONIFRATRÓW W KRAKOWIE. ŹRÓDŁO DO BADAŃ MONODII ŁACIŃSKIEJ
}

\section{Streszczenie}

W Archiwum Konwentu Bonifratrów w Krakowie znajduje się rękopiśmienny procesjonał z 1811 roku. Autor artykułu dokonał krytyki źródła i porównał jego zawartość z Processionale Andrzeja Piotrkowczyka z 1621 r., stanowiącym podstawę wykonywania śpiewów procesyjnych w Polsce przez około 200 lat, oraz wybranymi kancjonałami XIX wieku. Egzemplarz krakowski, będący prawdopodobnie jedną $\mathrm{z}$ ostatnich powstałych wówczas tego typu ksiąg, jest dowodem wysokiej kultury muzycznej kultywowanej w środowisku, dla którego powstał oraz świadectwem pielęgnowania żywej tradycji organizowania procesji. Potwierdza w tym względzie wyraźną przewagę ksiąg polskich nad rzymskimi, z coraz większym udziałem ludu wykonującego śpiewy w języku polskim. Przedruk znacznej zawartości procesjonału w wydawanych następnie kancjonałach potwierdza ewidentnie wartość i przydatność tej księgi.

Słowa kluczowe: monodia łacińska; rękopis; Processionale; Cantionale ecclesiasticum; bonifratrzy.

\author{
A NINETEENTH-CENTURY PROCESSIONAL FROM THE ARCHIVE \\ OF THE BONIFRATRES IN CRACOW (KRAKÓW). \\ A CONTRIBUTION TO RESEARCH INTO LATIN MONODY
}

\section{Summary}

The Archive of the Bonifratres' Monastery in Cracow holds a handwritten processional from 1811. The present author has conducted source criticism and compared its contents to Andrzej Piotrkowczyk's Processionale from 1621 - which furnished a basis for the performance of processional chants in Poland for around 200 years - and selected nineteenth-century cancionals. The Cracow item, probably one of the last books of this type in this period, is proof of the high musical culture that was cultivated in the milieu for which it was destined, and a testimony of the cherished, living tradition of organizing processions. In this respect, it confirms the clear advantage of Polish books over Roman ones, with an increasing participation of the people chanting in Polish. The reprint of a greater part of the processional in subsequently published cancionals confirms, as a matter of evidence, the value and utility of this book.

Key words: Latin monody; manuscript; Processionale; Cantionale ecclesiasticum; Bonifratres. 